ECONONMC \& EDUCATION

JOURNAL

ECODUCATION

\title{
PENGARUH SERTIFIKASI TERHADAP KINERJA GURU DI KECAMATAN ARJASA KEPULAUAN KANGEAN
}

\author{
Ach. Sugianto, IKIP Budi Utomo Malang \\ Loesita Sari, M.Pd, IKIP Budi Utomo Malang \\ Deni Nugroho S., S.E., M.Sa, IKIP Budi Utomo Malang \\ email: radennanda051@gmail.com
}

\begin{abstract}
Abstrak
Tujuan dari penelitian ini 1.Untuk mengetahui kinerja guru sebelum menerima sertifikasi di kecamatan arjasa kepulauan kangean. 2. Untuk mengetahui kinerja guru sesudah menerima sertifikasi di kecamatan arjasa kepulauan kangean. 3. Untuk mengetahui apakah terdapat pengaruh penerimaan sertifikasi guru terhadap kinerja guru di kecamatan arjasa kepulauan kangean. Penelitian ini menggunakan metode penelitian deskriptif dengan pendekatan kuantitatif yang berfukus pada perbandingan antar variable yaitu variable $\mathrm{X}$ dan variable $\mathrm{Y}$. Populasi penelitian ini adalah guru di kecamatan arjasa. Sedangkan sampel gugu-guru yang memiliki sertifikasi. Teknik pengumpulan data dengan cara wawancara dan dokumentasi. Teknik pengolahan data yaitu dengan tahap editing, tahap analisis data dengan rumus regresi sedehana menggunanakan spss, dan terakhir dengan tahap interpretasi. Pada penghitungan hipotesis diperoleh nilai pada $\mathrm{t}$ table $=$ signifikan $5 \% \mathrm{df}=\mathrm{N}-1$ (30-1) yaitu 29 dengan nilai t hitung $=10.800$ dan $\mathrm{t}$ table sebesar $=2.045$ dengan nilai signifikan $(10.800>2.045)$. hal ini berarti hipotesis yang diajukan peneliti diterima yaitu terdapat pengaruh yang positif dan signifikan dalam penelitian yang berjudul "Pengaruh Sertifikasi Terhadap Kinerja Guru di Kecamatan Arjasa Kepulauan Kangean" dapat teruji kebenarannya. Dengan demikian dapat disimpulkan bahwa sertifikasi sangat berpengaruh dan signifikan terhadap kinerja guru. Dalam artian bahwa penelitian ini mampu menjawab kebenaran hipotesis yang diajukan.
\end{abstract}

Kata kunci : Sertifikasi, Kinerja Guru

\section{Abstract}

The purpose of this study is 1. To find out the teacher's performance before receiving certification in the arjasa sub-district of Kangean Islands. 2. To find out the teacher's performance after receiving certification in the arjasa sub-district of Kangean Islands. 3. To find out whether there is an effect of receiving teacher certification on teacher performance in arjasa sub-district, kangean islands. This study uses a descriptive research method with a quantitative approach that is fusible on comparisons between variables namely variable $X$ and variable $Y$. The population of this study is teachers in the arjasa sub-district. While the gugu-teacher samples are certified. Data 
collection techniques by interview and documentation. Data processing techniques, namely with the editing stage, the stage of data analysis with a simple regression formula using MSS, and finally with the stage of interpretation. In calculating the hypothesis obtained value at $t$ table $=$ significant $5 \% d f=N-1$ (30-1) which is 29 with a value of $t$ arithmetic $=$ 10.800 and $t$ table of $=2.045$ with a significant value $(10,800>2,045)$. this means that the hypothesis proposed by the researcher is accepted, namely that there is a positive and significant influence in the study entitled "The Effect of Certification on Teacher Performance in Arjasa District, Kangean Islands" can be verified. Thus it can be concluded that certification is very influential and significant for teacher performance. In the sense that this research is able to answer the truth of the hypothesis proposed.

Keywords: Certification, Teacher Performance.

\section{PENDAHULUAN}

Dalam proses sosialisasi ini terdapat agen- agen sosialisasi, yaitu keluarga, teman bermain, sekolah, dan media massa. Dalam keluarga, orang tua yang mengajarkan anaknya cara bersosialisasi dengan lingkungan keluarga, setelah dapat berpergian, seorang anak akan memperoleh agen sosialisasi lainnya, yaitu teman bermain, baik yang terdiri atas kerabat, tetangga, dan teman sekolah. Selanjutnya sekolah menjadi agen sosialisasi yang akan membentuk kepribadian seorang anak, dan yang terakhir adalah media massa sebagai agen sosialisasi yang mampu membentuk perilaku khalayaknya .melalui perkembangan teknologi.

Sekolah merupakan agen sosialisasi pendidikan dalam bentuk sistem formal. Ketika seorang anak masuk ke sekolah, maka akan bertemu dengan teman-teman yang baru dan guru-guru yang akan membimbing ketika berada di sekolah. Guru adalah seorang administrator, informator, dan konduktor yang memiliki peranan penting di sekolah. Sebagai pendidik dan pembangun generasi baru, diharapkan guru dapat bertingkahlaku, berakhlak, dan bermoral tinggi karena apa yang dilakukan guru akan menjadi contoh bagi anak muridnya.

Belajar pada hakikatnya adalah proses intraksi terhadap situasi yang ada disekitr individu. Belajar juga merupakan proses melihat, mengamati, dan memahami sesuatu yang dipelajarinya (Oemar .2001). Kegiatan pemelajaran dilakukan oleh dua pelaku, yaitu guru dan siswa. Perilaku guru adalah mengajarkan apa yang harus diajarkan dan perilaku siswa adalah belajar dengan bahan pembelajaran berupa pengetahuan, nilai-nilai kesusilaan, seni, agama, sikap, dan keterampilan. Untuk mencapai keberhasilan dalam proses pembelajaran, terdapat beberapa komponen yang menunjang di dalamnya yaitu komponen tujuan, komponen materi, komponen strategi belajar mengajar, dan komponen evaluasi.

Proses belajar mengajar merupakan inti dari proses kegiatan pendidikan formal yang ada di sekolah dengan guru sebagai peranan utama. Menurut Usman (dalam Oemar, 2001) menyebutkan bahwa: proses belajar mengajar adalah suatu proses yang mengandungserangkaian perbuatan guru dan siswa yang mendasari adanya hubungan timbal-balik yang berlangsung 
dalam suasana edukatif untuk mencapai tujuan tertentu.

Guru adalah orang yang pekerjaannya (mata pencahariannya, profesinya) mengajar. Dalam undang undang Nomer 23 tahun 2003 (dalam Martinis, 2009) tentang Sistem Pendidikan Nasional pasal 39 : 2 menjelaskan bahwa: "pendidik merupakan tenaga profesional yang bertugas merencanakan pembelajaran, melaksanakan proses pembelajaran, menilai hasil pembelajaran, melakukan bimbingan dan pelatihan, serta melakukan penelitian dan pengabdian kepada masyarakat, terutama bagi pendidik perguruan tinggi".. dalam hal ini,ketentuan umum pasal 1 butir 5 menyatakan pengertian pendidik sebaagai beriku : pendidik adalah tenaga kependidikan yang berkualifikasi sebagai guru, dosen, konselor, pamong belajar, widyaiswara, tutor, instruktur, fasilitator, dan sebutan lain yang sesuai/pas dengan kekhususannya, serta bepartisipasi dalam penelenggaraan pendidikan.

Pendidikan merupakan kunci untuk mengembangkan suatu bangsa. Tanpa adanya pendidikan manusia di ibaratkan berada di dalam ruangan yang tertutup dan dengan adanya pendidikan seseorang akan berada di rungan yang terbuka terhadap dunia luar. Dalam pelaksanaan pendidikan guru adalah pemegang kunci untuk mengembangkan suatu bangsa dan dianggap sebagai agen yangpaling kuat dari perubahan sosial. Salah satu aspek yang menarik untuk dikaji dari seorang guru yaitu aspek kinerja, karena kinerja guru merupakan input yang penting dalam penyelenggaraan pendidikan. Fakta menunjukan kinerja guru masih belum optimal. Ditemukan guru-guru yang tidak membuat Rencana Pelaksanaan

Pembelajaran (RPP), mengabaikan kelengkapan administrasi guru, memberikan tugas tanpa adanya proses bertatap muka, penggunaan model dan metode yang masih monoton, dan evaluasi pembelajaran yang belum optimal.

\section{KAJIAN LITERATUR Tinjauan tentang Guru}

Definisi guru diatur dalam Undangundang Nomor 14 Tahun 2005 (Pasal 1 ayat 1) tentang Guru dan Dosen (dalam Martines, 2009). Guru adalah pendidik profesional dengan tugas utama mendidik, mengajar, membimbing, mengarahkan, melatih, menilai, dan mengevaluasi peserta didik pada jenjang pendidikan anak usia dini, pendidikan dasar, dan pendidikan menengah pada jalur pendidikan formal.

Guru memiliki tugas utama untuk mendidik, mengajar, membimbing, mengarahkan, melatih, menilai, dan mengevaluasi peserta didik, maka akan dijelaskan tentang rincian dari tugas utama guru tersebut.

\section{Kesejahteraan Guru}

Menurut Depdiknas 2001 (dalam Rusman, 2012), kesejahteraan adalah hal atau keadaan sejahtera, aman, selamat, dan tentram. Sedangkan pengertian keluarga sejahtera menurut BKKBN (1994: 5), yaitu keluarga yang dibentuk berdasarkan perkawinan yang sah, mampu memenuhi kebutuhan hidup spiritual dan materi yang layak, bertaqwa kepada Tuhan Yang /maha Esa, memiliki hubungan yang selaras, serasi, dan seimbang antar anggota dan antar keluarga dengan masyarakat dan lingkungan.

Berdasarkan pengertian kesejahteraandan keluarga sejahtera, dapat 
disimpulkan bahwa kesejahteraan guru yaitu kondisi terpenuhinya kebutuhan material dan sosial guru agar dapat hidup layak dan mampu mengembangkan diri sehingga dapat melaksanakan fungsi sosialnyasebagai guru.

Indikator tahapan keluarga sejahtera menurut $\mathrm{BKKBN}$ dibagi menjadi tiga yaitu, indikator "kebutuhan dasar keluarga" (basic needs) yang meliputi:Pada umumnya anggota keluarga makan dua kali sehari atau lebih.Anggota keluarga memiliki pakaian yang berbeda untuk di rumah, bekerja/sekolah dan bepergian.Rumah yang ditempati keluarga mempunyai atap, lantai dan dinding yang baik.Bila ada anggota keluarga sakit dibawa ke sarana kesehatan.Bila pasangan usia subur ingin ber $\mathrm{KB}$ pergi ke sarana pelayanan kontrasepsi. (Hanya untuk keluarga yang berstatus Pasangan Usia Subur).Semua anak umur 7-15 tahun dalam keluarga bersekolah.

\section{Tinjauan tentang Kinerja Guru}

Istilah kinerja berasal dari kata job performance/actual performance yang dapat diartikan sebagai prestasi kerja atau prestasi sesungguhnya yang dicapai oleh seseorang. Guru dapat mencapai kinerja yang maksimal jika guru mau berusaha untuk mengembangkan seluruh kompetensi yang dimilikinya dan juga memanfaatkan serta menciptakan situasi yang ada di lingkungan sekolah sesuai dengan aturan yang berlaku. Kinerja (prestasi kerja) sebagai hasil kerja secara kualitas dan kuantitas yang dicapai oleh seorang pegawai dalam melaksanakan tugasnya sesuai dengan tanggung jawab yang diberikan.

Kemudian menurut Ivor K. Davies (dalam Rusman, 2012) mengatakan bahwa ada empat ciri seseorang yang memiliki pekerjaan sebagai guru, ciri-ciri tersebut adalah merencanakan, yaitu pekerjaan seorang guru menyusun tujuan belajar. Mengorganisasikan, yaitu pekerjaan seorang guru untuk mengatur dan menghubungkan sumber-sumber belajar sehingga dapat mewujudkan tujuan belajar dengan cara yang paling efektif, efesien, dan seekonomis mungkin.Memimpin, yaitu pekerjaan seorang guru untuk memotivasi, mendorong, dan menstimulasikan murid-muridnya sehingga peserta didik siap mewujudkan tujuan belajar. Mengawasi, yaitu pekerjaan seorang guru untuk menentukan apakah fungsinya dalam mengorganisasikan dan memimpin di atas telah berhasil dalam mewujudkan tujuan yang telah dirumuskan. Jika tujuan belum dapat diwujudkan, maka guru harus menilai dan mengatur kembali situasinya.

Ada beberapa indikator yang dapat dilihat sebagai peran guru dalam meningkatkan kemampuan peserta didik agar dapat menerima materi pembelajaran dengan baik melalui proses belajarmengajar yang diadakannya. Indikatorindikator kinerja tersebut adalah : Sebelum melaksanakan kegiatan pembelajaran, guru dituntut menyusun rencana pembelajaran, fungsi perencanaan pembelajaran ialah untuk mempermudah guru dalam melaksanakan tugas selanjutnya, Sehingga proses belajar mengajar akan benar-benar terskenario dengan, efektif dan efesien. Kemapuan merencanakan kegiatan belajar mengajar ini meliputi:Menguasai Garisgaris Besar Penyelenggaraan Pendidikan. Menyesuaikan Analisa Materi Pelajaran. Menyusun Program Semester.Menyusun Program Pembelajaran. 
Setelah menyusun

rencana pembelajaran, tugas guru selanjutnya adalah melaksanakan pembelajaran yang merupakan aktivitas utama di sekolah. Guru harus menunjukkan penampilan yang terbaik bagi para siswanya, penjelasan materi harus mudah dipahami, penguasaan keilmuannya benar, menguasai metodologi, dan seni pengendalian siswa. Seorang guru juga harus bisa menjadi teman belajar yang baik bagi para siswanya sehingga siswa merasa senang dan termotivasi belajar bersamanya. Kemampuan melaksanakan kegiatan belajar mengajar ini meliputi:Tahap Preinstruk-sional. Tahap Instruksional. Tahap Evaluasi.

Langkah guru berikutnya adalah mengevaluasi hasil pembelajaran. Segala sesuatu yang terencana harus dievaluasi agar dapat diketahui apakah yang telah direncanakan sesuai dengan realisasinya dan tujuan yang ingin dicapai, serta untuk mengetahui apakah siswa telah dapat mencapai standar kompetensi yang di tetapkan, juga dapat mengetahui apakah metode ajarannya telah tepat sasaran. Dalam melakukan kegiatan evaluasi, seorang guru Harus memperhatikan tujuan pembelajaran yang telah ditetapkan serta harus memperhatikan soal-soal evaluasi yang digunakan agar dapat dapat mengukur kemampuan siswa. Kemampuan mengevaluasi hasil pembelajaran ini meliputi: Evaluasi Normatif. Evaluasi Formatif. Laporan Hasil Evaluasi. Pelakanaan Program Perbaikan.

Setiap lembaga pendidikan telah dibuat aturan-aturan yang harus diindahkan oleh para guru maupun tenaga pendidikan lainnya, bahkan sebagai pegawai negeri.
Aturan-aturan tersebut telah dibakukan menjadi aturan kepegawaian. Hal ini untuk menjadikan kelancaran pada jalanya proses belajar mengajar maupun citra baik dari masyarakat yang ingin memanfaatkan jasa lembaga tersebut.

\section{Tinjauan tentang Sertifikasi Guru}

Istilah sertifikasi dalam kamus berarti surat keterangan dari lembaga berwenang yang diberikan kepada jenis profesi dan sekaligus pernyataan terhadap kelayakan profesi untuk melaksanakan tugasnya yang diemban. Sertifikasi secara yuridis menurut ketentuan pasal 1 ayat (11) UUGD menyatakan adalah proses pemberian sertifikat pendidik kepada guru atau dosen.

Adapun yang berkaitan dengan sertifikasi guru dan dosen, dijabarkan dalam pasal 1 ayat (7) bahwa sertifikasi adalah proses pemberian sertifikat pendidik untuk guru. Sertifikasi guru merupakan pemenuhan kebutuhan untuk meningkatkan kompetensi profesional guru. Proses sertifikasi dipandang sebagai bagian dari esensial dalam upaya untuk memperoleh sertifikat, kompetensi harus sesuai dengan standar yang telah ditetapkan.

Menurut Mulyasa yang dimaksud sertifikasi guru adalah proses uji kompetensi yang dirancang untuk mengungkapkan penguasaan kompetensi seorang guru sebagai landasan untuk memberikan sertifikat pendidik. Selanjutnya berdasarkan Undang-undang tentang Guru dan Dosen No. 14 Tahun 2005 pada Pasal 1 ayat 11 yang mengemukakan maksud sertifikasi adalah pemberian sertifikat pendidik untuk guru dan dosen. Kemudian pada ayat 12 menjabarkan bahwa sertifikat pendidik 
adalah bukti yang formal sebagai pengakuan yang diberikan kepada guru dan dosen sebagai tenaga profesional.

Secara yuridis dasar hukum kewajiban sertifikasi bagi guru terdapat dalam Undang-Undang No. 14 Tahun 2005 tentang Guru dan Dosen yang disyahkan pada tanggal 30 Desember 2005. Pasal 8 menjabarkan bahwa guru profesional wajib memiliki kualifikasi akademik, kompetensi sertifikat pendidik, sehat jasmani dan rohani, serta memiliki kemampuan dan niat untuk mewujudkan pendidikan nasional. Pasal 11 ayat (1) mengemukakan bahwa sertifikat pendidik hanya diberikan kepada guru yang telah memenuhi persyaratan dan kelayakannya. Adapun syarat untuk memperoleh sertifikat pendidikan menurut pasal 9 adalah seorang guru harus memiliki kualifikasi pendidikan tinggi minimal program Strata Satu (S-1) atau program Diploma Empat (D-4).

Landasan hukum lainnya tertera dalam Undang-Undang No. 20 Tahun 2003 tentang Sistem Pendidikan Nasional (SISDIKNAS) dan Peraturan Menteri Pendidikan Nasional No. 18 Tahun 2007 tentang Sertifikasi Guru Dalam Jabatan yang ditetapkan pada tanggal 4 Mei 2007. Pasal yang mengatakannya adalah pasal ayat (1) yang berbunyi sertifikasi bagi jabatan seorang guru merupakan pemberian sertifikat pendidik untuk guru dalam jabatan, dan (2) sertifikasi yang telah dimaksud dalam ayat (1) dapat diikuti oleh guru dalam jabatan yang telah memiliki kualifikasi akademik Strata Satu (S-1) atau Diploma Empat (D-4).

Undang-Undang Guru dan Dosen Tahun 2005 mengemukakan bahwa sertifikasi merupakan bagian dari peningkatan mutu seorang guru serta untuk meningkatkan kesejahteraannya. Oleh karena itu, dengan adanya sertifikasi diharapkan guru mampu menjadi pendidik yang profesional dan berkompetensi sebagai agen pembelajaran yang dibuktikan dengan pemilikan sertifikat pendidik yang telah dinyatakan lulus uji kompetensi. Atas profesinya itu, guru akan mendapatkan imbalan (reward) berupa tunjangan profesi dari pemerintah. Setiap pelaksanaan kegiatan yang dilakukan akan mempunyai tujuannya masing- masing, dengan diadakannya program sertifikasi.

Adapun tujuan dari diadakannya program sertifikasi yaitu: Menentukan kelayakan guru dalam melaksanakan tugas sebagai agen pembelajaran dan mewujudkan tujuan pendidikan nasional. Meningkatkan proses dan mutu hasil pendidikan. Meningkatkan martabat guru. Meningkatkan profesionalitas guru.

\section{METODE PENELITIAN}

Penelitian ini menggunakan metode penelitian deskriptif dengan pendekatan kuantitatif yang berfukus pada perbandingan antar variable yaitu variable $\mathrm{X}$ dan variable $\mathrm{Y}$. Populasi penelitian ini adalah guru di kecamatan arjasa. Sedangkan sampel gugu-guru yang memiliki sertifikasi. Teknik pengumpulan data dengan cara wawancara dan dokumentasi. Teknik pengolahan data yaitu dengan tahap editing, tahap analisis data dengan rumus regresi sedehana menggunanakan spss, dan terakhir dengan tahap interpretasi.
HASIL DAN
PEMBAHASAN PENELITIAN

Kinerja guru sebelum sertifikasi 
Berdasarkan hasil penelitian ini, nilai interval kinerja guru sebelum menerima sertifikasi dapat diuraikan dengan hasil yang didapat dari hasil penelitian yang dilakukan yaitu untuk kualifikasi A sebanyak 4 guru dengan persentasi $13.3 \%$. Guru yang sudah berpengalaman dalam kegiatan belajar mengajar di sekolah, sehingga lebih professional dalam menjalankan tugasnya sebagai guru. Untuk kualifikasi B sebanyak 17 guru dengan persentasi 56.7\%.Guru yang belum berpengalaman dalam kegiatan belajar mengajar di sekolah, sehingga masih perlu untuk melatih dirinya untuk menjadi profesioanal dalam menjalankan tugasnya sebagai guru. untuk kualifikasi $\mathrm{C}$ sebanyak 9 guru dengan persentasi 30\%. Guru yang masih terbilang baru dalam kegiatan belajar mengajar di sekolah, sehingga harus menyesuaikan dulu terhadap lingkungan sekolah dan metode pembelajran yang digunakan di sekolah dalam menjalankan tugasnya sebagai guru.

\section{Kinerja guru sesudah sretifikasi}

Berdasarkan hasil penelitian ini, nilai interval kinerja guru sesudah menerima sertifikasi dapat diuraikan dari hasil yang didapat oleh hasil analisis data yang dilakukan yaitu untuk kualifikasi A sebanyak 8 guru dengan persentasi $26.7 \%$. Guru yang sudah berpengalaman dalam kegiatan belajar mengajar di sekolah, sehingga lebih professional dalam menjalankan tugasnya sebagai guru.Untuk kualifikasi B sebanyak 21 guru dengan persentasi $70 \%$, Guru yang belum berpengalaman dalam kegiatan belajar mengajar di sekolah, sehingga masih perlu untuk melatih dirinya untuk menjadi profesioanal dalam menjalankan tugasnya sebagai guru.Untuk kualifikasi C sebanyak
1 guru dengan persentasi 3.3\%. Guru yang masih terbilang baru dalam kegiatan belajar mengajar di sekolah, sehingga harus menyesuaikan dulu terhadap lingkungan sekolah dan metode pembelajran yang digunakan di sekolah dalam menjalankan tugasnya sebagai guru.

\section{Pengaruh penerimaan sertifikasi terhadap kinerja guru}

Variable pertama (variable entered/removed). Table di atas menjelaskan tentang variable yang di masukkan atau di buang dan metode yang digunakan. Dalam hal ini variable yang dimasukkan adalah variable kinerja guru sebelum menerima sertifikasi sebagai predictor dan metode yang digunakan adalah metode enter. Variable bagian kedua (model summary). Table ini menjelaskan besarnya nilai korelasi / hubungan $\mathrm{R}$ yaitu sebesar 0.898 dan dijelaskan besarnya persentase pengaruh variable bebas yerhadap variable terikat yang disebut koefisien determinasi (R2) sebesar 0.806 yang memiliki makna bahwa pengaruh variable bebas terhadap bariabel terikat adalah sebesar $80.6 \%$, sedangkan sisanya $19.4 \%$ dipengaruhi oleh variable yang lain yang tidak diteliti.

Variable bagian ketiga (annova). Table ini menjelaskan apakah ada pengaruh yang nyata (signifikan) antara variable independent dan variable dependent. Dari table terlihat bahwa nilai regresi memiliki tingkat signifikan 0.000 , nilai ini lebih kecil dari 0.05 atau sig $<\alpha$, ini berarti hipotesis penelitian yang menyatakan "pengaruh sertifikasi terhadap kinerja guru" diterima. Dengan demikian model persamaan regresi berdasarkan data penelitian memenuhi criteria linearitas. 
Variable bagian keempat (coefficients). Dari table di atas dapat dilihat bahwa nilai constant (a) untuk variable Xadalah 1.166, sedangkan hasil nilai koefisien untuk variable $X$ adalah 0.719.dengan demikian dapat dibuat persamaan regresi linear dengan mengacu pada rumus sebagai berikut :

$Y^{\prime}=a+b X$

$Y^{\prime}=1.166+0.719 X$

Persamaan regresi $\mathrm{Y}^{\prime}=1.166+0.719$, kemudian diuji apakah memang valid untuk memprediksi variabel terikatnya. Artinya apakah variable $\mathrm{X}$ benar-benar dapat memprediksi variable Y. hasil dari analisis di atas terbukti bahwa koefisien konstanta pada model linier $(\alpha)$ signifikan karena nilai signifikan dari adalah 0,000, jauh lebih besar dari 0,05. Kemudian hasil dari uji signifikansi koefisien regresi variabel $\mathrm{X}(b)$ menunjukkan signifikan karena nilai signifikan dari adalah 0,000, jauh lebih besar dari taraf signifikan 5\% atau 0,05. Koefisien konstanta padamodel linier $(b)$ dan koefisien regresi variabel $\mathrm{X}$ $(\alpha)$ signifikan. jadi variable $X$ berpengaruh terhadap variable $\mathrm{Y}$.

Sehingga persamaan regresi dapat dijelaskan sebagai berikut:

1. Nilai konstanta memiliki nilai 1.166, artinya jika variable $\mathrm{X}$ nilainya 0 , maka variable Y nilainya 1.166.

2. Koefisien regresi $X$ sebesar 0.719, artinya setiap penambahan nilai 1 satuan, maka nilai variable Y sebesar 0.719. Dan sebaliknya jika nilai variable $\mathrm{X}$ turun 1 poin maka nilai dari variable $\mathrm{Y}$ juga mengalami penurunan sebesar 0,719 poin.

Interpretesi dari persamaan di atas adalah bahwa koefisien regresi variable $\mathrm{X}$ memiliki tanda positif (0.719), yaitu mengandung implikasi bahwa variable $\mathrm{X}$ searah dengan variable $Y$. dengan kata lain bahwa variable $\mathrm{X}$ mempunyai pengaruh yang positif terhadap variable Y.

Dapat juga disimpulkan dengan uji $t$ yaitu untuk mengetahui apakah diterima atau tidaknya hipotesis variable $\mathrm{X}$ terhadap variable Y.Untuk melakukan uji $t$ digunakan table coefficient, seperti yang telah tercantum pada table 4.6 di atas. Berdasarkan table tersebut diperoleh $\mathrm{t}$ hitung sebesar 10.800 pada tingkat sig 0.000.untuk $\mathrm{t}$ table diperoleh sebesar 2.045. hasil uji $\mathrm{t}$ itu dikaitkan dengan hipotesis pertama yang diajukan dalam penelitian ini yaitu :

Ho : tidak ada pengaruh yang nyata antara variable $X$ terhadap variable $Y$

Ha : ada pengaruh yang nyata antara variable $\mathrm{X}$ terhadap variable $\mathrm{Y}$

Kriteria diterimanya hipotesis :

Jika t-hitung $<\mathrm{t}$ table dan sig $>0.05$, maka Ho ditolak dan Ha diterima.

Jika t hitung $>\mathrm{t}$ table dan sig $<0.05$, maka Ha diterima dan Ho ditolak.

Taraf penghitungan $=5 \%$ derajat kebebasan $(\mathrm{df})=\mathrm{n}-1=30-1=29$

Berdasarkan pada penghitungan hipotesis diperoleh nilah pada $\mathrm{t}$ table $=$ signifikan $5 \%$ df $=\mathrm{N}-1(30-1)$ yaitu 29 dengan nilai $\mathrm{t}$ hitung $=10.800$ dan t table sebesar $=2.045$ dengan nilai signifikan $(10.800>2.045)$. hal ini berarti hipotesis yang diajukan peneliti diterima yaitu terdapat pengaruh yang positif dan signifikan dalam penelitian yang berjudul "Pengaruh Sertifikasi Terhadap Kinerja Guru di Kecamatan Arjasa Kepulauan Kangean" dapat teruji kebenarannya. Dengan demikian dapat disimpulkan bahwa sertifikasi (sebelum dan sesudah) sangat berpengaruh dan signifikan 
terhadap kinerja guru. Dalam artian bahwa penelitian ini mampu menjawab kebenaran hipotesis yang diajukan.

\section{KESIMPULAN DAN SARAN}

Kinerja guru sebelum menerima sertifikasi yaitu untuk kualifikasi A sebanyak 4 guru dengan persentasi $13.3 \%$. Untukkualifikasi B sebanyak 17 guru dengan persentasi $56.7 \%$. untuk kualifikasi C sebanyak 9 guru dengan persentasi $30 \%$.

Kinerja guru sesudah menerima sertifikasi yaitu untuk kualifikasi A sebanyak 8 guru dengan persentasi $26.7 \%$. Untuk kualifikasi B sebanyak 21 guru dengan persentasi $70 \%$, Untuk kualifikasi $\mathrm{C}$ sebanyak 1 guru dengan persentasi $3.3 \%$.

Berdasarkan pada penghitungan hipotesis diperoleh nilah pada $\mathrm{t}$ table $=$ signifikan $5 \%$ df $=\mathrm{N}-1(30-1)$ yaitu 29 dengan nilai $\mathrm{t}$ hitung $=10.800$ dan $\mathrm{t}$ table sebesar $=2.045$ dengan nilai signifikan (10.800>2.045). hal ini berarti

hipotesis yang diajukan peneliti diterima yaitu terdapat pengaruh yang positif dan signifikan dalam penelitian yang berjudul "Pengaruh Sertifikasi Terhadap Kinerja Guru di Kecamatan Arjasa Kepulauan Kangean" dapat teruji kebenarannya. Dengan demikian dapat disimpulkan bahwa sertifikasi (sebelum dan sesudah) sangat berpengaruh dan signifikan terhadap kinerja guru.

\section{DAFTAR RUJUKAN}

Abubakar, Asnandar. 2015. Dampak

Sertifikasi Guru Terhadap Kualitas

Pendidikan Pada Madrasah Aliyah Di

Kota Kendari. 21(1): 117-128

Azwar Khairul; Yusrizal; Murniati Ar.

2015. Pengaruh Sertifikasi Dan
Kinerja Guru Terhadap Peningkatan

Hasil Belajar Siswa Di Smp Negeri 2

Banda Aceh. Administrasi

Pendidikan, 3(2): 138-147

Budiharto. 2013. Sertifikasi Guru Sebagai

Upaya Meningkatkan Profesionalisme

Guru dalam Rangka Meningkatkan

Kualitas Pendidikan. 39(2): 115-128.

Danim, Sudarwan. 2010. Karya Tulis

Inovasi. Sebuah Pengembangan

Profesi Guru. Bandung: Remaja

Rosdakarya.

Djamarah, Syaiful Bahri dan Aswan Zain. 2010. Strategi Belajar Mengajar. Jakarta: Rineka Cipta.

Hamalik, Oemar. 2001. Proses Belajar Mengajar. Jakarta: Bumi Aksara.

Ibrahim, R dan Nana Syaodih S. 2010. Perencanaan Pengajaran. Jakarta: Rineka Cipta

Mulyasa, E. 2011. Menjadi Guru Profesional: Menciptakan Pembelajaran Kreatif Dan Menyenangkan. Bandung: Remaja Rosdakarya.

Mulyasa, H.E. 2013. Uji Kompetensi Dan Penilaian Kinerja Guru. Banduang: Remaja Rosdakarya.

Rasto, Koswara. 2016. Kompetensi Dan

Kinerja Guru Berdasarkan Sertifikasi

Profesi. Pendidikan Manajemen

Perkantoran, 1(1): 64-74.

Rusman.

2012.

Model-Model

Pembelajaran: Mengembangkan

Profesionalisme Guru. Ed. 2. Jakarta: Rajawali Pers.

Syah, Muhibbin. 2014. Psikologi

Pendidikan. Bandung: Remaja

Rosdakarya.

Sugiyono. 2012. Metode Penelitian

Pendidikan: Pendekatan Kuantitatif, 
Kualitatif, Dan $R \& D$. Bandung: Alfabeta.

Sunanik. 2015. Pengaruh Sertifikasi Guru Terhadap Kinerja Guru Smpn 1 Durenan. Efektor.Unpkediri.Ac.Id, 1(26): 73-84.

Wahyudi, Imam. 2012. Pengembangan

Pendidikan : Strategi Inovtif Dan

Kreatif Dalam Mengelola Pendidikan

Secara Komprehensif. Jakarta:

Prestasi Pustakarya.
Wibowo, Agung Edy. 2012. Aplikasi Praktis SPSS dalam Penelitian. Yogyakarta: Gava Media.

Yamin, H. Martinis. (Eds). 2009.

Sertifikasi Profesi Keguruan Di

Indonesia: Dilengkapi UU No.14

Tahun 2005 Tentang Guru Dan

Dosen. Jakarta: Gaung Persada Press.

\section{Lampiran}

Table 1

Kinerja Guru Sebelum Sertifikasi

\begin{tabular}{|l|l|l|l|l|}
\hline Nilai & Predikat & Huruf & Frekuensi & Persentasi \\
\hline $36-4$ & Sangat baik & A & 8 & $26.7 \%$ \\
\hline $3-35$ & Baik & B & 21 & $70 \%$ \\
\hline $26-3$ & Cukup baik & C & 1 & $3.3 \%$ \\
\hline $2-25$ & Kurang baik & D & - & - \\
\hline $16-2$ & Sangat kurang & E & - & - \\
\hline$\sum$ & & 30 & $100 \%$ \\
\hline Mean & & \multicolumn{3}{|c|}{3.4} \\
\hline
\end{tabular}

Tabel 2

kinerja guru sesudah sertifikasi

\begin{tabular}{|l|l|l|l|l|}
\hline Nilai & Predikat & Huruf & Frekuensi & Persentasi \\
\hline $36-4$ & Sangat baik & A & 8 & $26.7 \%$ \\
\hline $3-35$ & Baik & B & 21 & $70 \%$ \\
\hline $26-3$ & Cukup baik & C & 1 & $3.3 \%$ \\
\hline $2-25$ & Kurang baik & D & - & - \\
\hline $16-2$ & Sangat kurang & E & - & - \\
\hline$\sum$ & & 30 & $100 \%$ \\
\hline Mean & \multicolumn{3}{|l|}{3.4} \\
\hline
\end{tabular}

Table 3

Variables Entered/Removed ${ }^{\mathbf{b}}$

\begin{tabular}{|l|l|l|l|}
\hline Model & Variable Entered & Variable removed & Method \\
\hline 1 & Sebelum sertifikasi & & Enter \\
\hline
\end{tabular}

Table 4

Model Summary

\begin{tabular}{|l|l|l|l|l|}
\hline Model & R & R Square & Adjusted R Square & Std. Error of the Estimate \\
\hline 1 & .898 & .806 & .799 & .09960 \\
\hline
\end{tabular}


Table 5

ANOVA

\begin{tabular}{|l|l|l|l|l|l|}
\hline Model & Sum of Squares & Df & Mean square & F & Sig \\
\hline 1 regression & 1.157 & 1 & 1.157 & 116.630 & .000 \\
Residual & .278 & 28 & .010 & & \\
Total & 1.435 & 29 & & & \\
\hline
\end{tabular}

Tabel 6

Coefficients $^{\mathrm{a}}$

\begin{tabular}{|l|l|l|l|l|l|}
\hline \multicolumn{1}{|c|}{ Model } & \multicolumn{2}{|c|}{ Unstandardized coefficients } & $\begin{array}{c}\text { Standardized } \\
\text { Coefficients }\end{array}$ & \multirow{2}{*}{$\mathrm{T}$} & sig \\
\cline { 1 - 5 } & \multicolumn{1}{|c|}{$\mathrm{B}$} & \multicolumn{1}{|c|}{ Std. error } & \multicolumn{1}{c|}{ Beta } & & \\
\hline 1 (constan) & 1.166 & .209 & & 5.579 & .000 \\
Sebelum sertifikasi & .719 & .067 & .898 & 10.800 & .000 \\
\hline
\end{tabular}

